\title{
Intravenous cannula can increase serum creatine kinase MB activity
}

\section{Muammer Yucel}

Department of Medical Biochemistry Laboratory, Kâtip Celebi University Ataturk Training and Research Hospital, Izmir, Turkey

\begin{abstract}
Objectives: Different blood sampling methods may result in differing creatine kinase $M B(C K-M B)$ results. The aim of this study was to assess the effect of 2 phlebotomy methods on the CK-MB level in serum samples of healthy adults.

Methods: The study used 50 volunteers (20 females, 30 males) who were employees at Baskent University Hospital in Ankara, Turkey. The subjects were randomly assigned to the study group. Blood samples were collected with the most widely used equipment for each method being tested (20G intravenous [IV] cannula and 20G needle unit) to compare the effects of different methods of blood sampling. The mean values of CK-MB and creatine kinase (CK) activity were compared using a paired samples t-test.

Results: The mean CK-MB activity was $14.4 \pm 4.1 \mathrm{U} / \mathrm{L}$ and the mean CK activity was $127.3 \pm 17.1 \mathrm{U} / \mathrm{L}$ in samples that were drawn with a $20 \mathrm{G}$ needle unit, while in samples drawn with a 20G IV cannula, the corresponding results were $19.3 \pm 3.8$ $\mathrm{U} / \mathrm{L}$ and $132.5 \pm 16.1 \mathrm{U} / \mathrm{L}$ ( $\mathrm{p}<0.001$ for both).

Conclusion: The study results indicated that blood sampling using an IV cannula caused more mechanical injury to vessel endothelium than sampling with a needle unit. This translates to greater interference with CK-MB and CK activity when the cannula method is used. Blood sampling with a cannula led to elevated CK-MB activity.

Keywords: Blood sampling, creatine kinase MB, hemolysis, interference, phlebotomy
\end{abstract}

C ardiac emergencies can be a cause of greater hospital mortality [1]. The level of creatine kinase MB (CK-MB) isoenzyme activity in serum is still an important marker in the differential diagnosis of acute chest pain and the planning of treatment for cardiac cases in hospitals where troponin and CK-MB mass tests cannot be performed [2]. However, different blood sampling methods used in the emergency room and the blood-sampling unit of the hospital laboratory may result in differing CK-MB results [3]. For example, when a patient with chest pain arrives at the emergency department, an intravenous (IV) cannula is immediately inserted and blood is drawn via this catheter. There are various factors that affect CK-MB activity. Even if the chest pain is not related to a cardiac etiology, the CK-MB activity value may be high with this collection method for other reasons, such as hemolysis. In some cases, CK-MB activity measured using an immunoinhibition technique may exceed the upper-normal limit, whereas CKMB mass measurements of the same sample may be in the normal range. Many laboratories still use immunoinhibition as the routine method to measure CK-MB activity in serum for several reasons $[4,5]$. In Izmir, the third largest city in Turkey, about 100.000 CK-MB activity tests per year are performed in 15 different state hospitals.

Hemolysis before blood analysis is a source of error in all clinical laboratories and may occur if the hemoglobin $(\mathrm{Hb})$ concentration in a sample is greater than $27 \mathrm{mg} / \mathrm{dL}$ [6]. Research has shown that measurements of hemolytic samples have indicated higher levels of CK-MB activity than actually existed in the sample (i.e., positive interference, depending on the intensity of hemolysis), and lower measurements of CK-MB mass (neg-

Address for correspondence: Muammer Yucel, MD. Department of Medical Biochemistry Laboratory, Kâtip Celebi University Ataturk Training and Research Hospital, Izmir, Turkey

Phone: +90 5326673097 E-mail: drmuammer@gmail.com ORCID: 0000-0002-1646-3953

Submitted Date: March 25, 2020 Accepted Date: April 09, 2020 Available Online Date: April 24, 2020

${ }^{\circ}$ Copyright 2020 by International Journal of Medical Biochemistry - Available online at www.internationalbiochemistry.com OPEN ACCESS This work is licensed under a Creative Commons Attribution-NonCommercial 4.0 International License. 
ative interference) [7]. It has also been established that hemolysis exaggerates measurements of creatine kinase (CK) as well as CK-MB activity, and this is interesting since erythrocytes do not contain CK [8]. Two primary theories for this effect have been proposed. One suggestion is related to the passage of adenylate kinase, adenosine triphosphate (ATP), and glucose6-phosphate from erythrocytes into the serum when these cells rupture. In the immunoinhibition method of blood testing, the action of released adenylate kinase produces high levels of ATP as a by-product. Both ATP and glucose-6-phosphate are substrates in CK and CK-MB reactions [9]. The second theory is that hemolysis increases the absorbance of light in the short wavelength of the visible spectrum $(300-500 \mathrm{~nm})[10,11]$. Such a change in absorbance would alter laboratory results.

The needle sizes most commonly used for drawing blood are gauges 19-22 (outside diameter 1.06-0.71 mm). Hemolysis is usually less severe when blood is drawn through a small-bore needle because there is less blood turbulence than with the use of a larger-bore needle [12].

The aim of this study was to assess how blood sampling phlebotomy methods affect CK and CK-MB levels in serum samples drawn from healthy adults.

\section{Materials and Methods}

The study included 50 volunteers (20 females and 30 males) who were employees at Baskent University Hospital in Ankara, Turkey. The average age of the volunteers was $30.3 \pm 4.11$ years (23-40 years). The Baskent University Faculty of Medicine Clinical Research Ethics Committee approved the protocol (No:

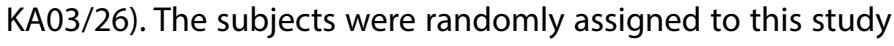
group. Blood samples were collected with the most widely used equipment for each method being tested (20G IV cannula and 20G needle unit) to compare the effects of different methods of blood sampling. A single phlebotomist performed all of the sampling, and the collections were performed in the blood-sampling unit of the study laboratory. Each specimen was $5 \mathrm{~mL}$ in volume and was drawn into a simple, plain biochemistry tube (BD Vacutainer; Becton, Dickinson and Company, Franklin Lakes, NJ, USA). Veins of similar diameter were used for all of the sampling, and the blood was drawn under conditions of minimal venous stasis. Each subject had 2 samples collected: the first from the right brachial vein, using a 20G IV cannula (BD Venflon, Becton, Dickinson and Company, Franklin Lakes, NJ, USA) and a second from the left brachial vein, using a $20 \mathrm{G}$ needle unit. After each sample was obtained, the blood was centrifuged at $2500 \times \mathrm{xg}$ for 10 minutes at room temperature. Then $1 \mathrm{~mL}$ of serum was separated off, and this was centrifuged for another 10 minutes at $2500 \times \mathrm{xg}$ at the same temperature. The activity level of CK and CK-MB was then analyzed using a PP Moduler autoanalyser (Roche Diagnostics, Basel, Switzerland). Serum CK activity was measured according to the CK N-acetyl cysteine (CK-NAC) method (CK-NAC Reagent, No. 1552147; Roche Diagnostics, Basel, Switzerland), using the guidelines of the International Federation of Clinical
Chemistry and the German Society for Clinical Chemistry [13]. Serum CK-MB activity was measured using the immunoinhibition method (CKMB Reagent, No. 1929011; Roche Diagnostics, Basel, Switzerland) [14]. The normal range of the CK test was 0-165 U/L for women and 0-190 U/L for men, and the CK-MB test was 0-25 U/L for both sexes. Intra-assay and inter-assay coefficient of variation (CV\%) measurements were performed for the CK and CK-MB tests. The ratio of CK-MB to CK was also calculated. The serum $\mathrm{Hb}$ concentration was measured with a Shimadzu UV-1208 spectrophotometer (Shimadzu Corp., Kyoto, Japan) with sodium carbonate working solution [15]. The rejection criteria of the study were hemolyzed samples and increased CK activity. Visual hemolysis was not observed in the serum samples. Each subject's serum total CK activity was in the normal range.

\section{Statistical analysis}

The data were analyzed using SPSS Statistics for Windows, Version 17.0 (SPSS Inc., Chicago, IL, USA). CK, CK-MB, and Hb results were reported as mean \pm SD. The Kolmogorov-Smirnov and Shapiro-Wilk tests were used to assess normality. The mean values for CK activity, CK-MB activity, and serum $\mathrm{Hb}$ concentration in the study group were compared using a paired samples t-test.

\section{Results}

The mean CK activity was $127.3 \pm 17.1 \mathrm{U} / \mathrm{L}$, the mean CK-MB activity was $14.4 \pm 4.1 \mathrm{U} / \mathrm{L}$, the ratio of CK-MB to $C K$ was $11.3 \pm 2.7 \%$, and the mean serum $\mathrm{Hb}$ concentration was $7.3 \pm 4.0 \mathrm{mg} / \mathrm{dL}$ in the samples drawn with a $20 \mathrm{G}$ needle unit. In the same group, in the samples drawn using a 20G IV cannula, the corresponding results were a mean of $132.5 \pm 16.1 \mathrm{U} / \mathrm{L}, 19.3 \pm 3.8 \mathrm{U} / \mathrm{L}$, $14.6 \pm 2.4 \%$, and $7.5 \pm 4.0 \mathrm{mg} / \mathrm{dL}$. Comparisons revealed significant differences between the CK results, the CK-MB results, and the ratio of $C K-M B$ to $C K(p<0.001$ for all). However, there was no significant difference in the $\mathrm{Hb}$ results in the group ( $p>0.05$ ) (Table 1). Intra-assay CV measurements for CK and CK-MB tests were $1.21 \%$ and $3.99 \%$, respectively. Inter-assay $\mathrm{CVs}$ for CK test in low- and high-level measurements were $1.93 \%$ and $1.55 \%$, respectively (mean inter-assay CV: $1.74 \%$ ). The inter-assay CV values for the CK-MB test were $4.19 \%$ and $2.48 \%$, respectively (mean inter-assay CV: $3.34 \%$ ).

\section{Discussion}

CK-MB is used as a marker for diagnosing the cause of chest pain, and CK-MB activity tests are still frequently used in district hospitals with low patient capacity and limited facilities. However, certain factors restrict the accuracy of this test. The level of CK-MB activity can be falsely elevated in the setting of hemolysis, hypothyroidism, uremia, muscle trauma and the presence of macro $\mathrm{CK}$, and the presence of elevated CKBB [16-19]. If a blood sample for CK-MB analysis is hemolyzed, a new one should be obtained. However, repeat sampling is 
Table 1. Laboratory findings using two methods of blood sampling

Blood sampling with 20G

needle unit $(n=50)$

mean \pm SD

\begin{tabular}{ll}
\hline CK-MB (U/L) & $14.4 \pm 4.1$ \\
CK (U/L) & $127.3 \pm 17.1$ \\
CK-MB/CK ratio $(\%)$ & $11.3 \pm 2.7$ \\
Free hemoglobin $(\mathrm{mg} / \mathrm{dL})$ & $7.3 \pm 4.0$
\end{tabular}

Free hemoglobin $(\mathrm{mg} / \mathrm{dL})$

\section{Blood sampling with}

20G IV cannula $(n=50)$

mean \pm SD

$19.3 \pm 3.8$
$132.5 \pm 16.1$
$14.6 \pm 2.4$

$7.5 \pm 4.0$ $\mathbf{p}$

$<0.001$

$<0.001$

$<0.001$

$>0.05$

CK: Creatine kinase; CK-MB: Creatine kinase MB

not performed in all cases with hemolytic samples because of the rapid turnaround time necessary for prompt diagnosis of myocardial infarction [8]. In this study group, the CK and CK-MB levels in the samples collected with a 20G IV cannula were higher than that seen in the samples collected with a needle unit. Also, the $\mathrm{Hb}$ concentration in the blood drawn with the IV cannula was higher than those drawn with the needle units, although the difference in the $\mathrm{Hb}$ level was not statistically significant. This may have been due to the gentle conditions of the blood draw. The findings indicate that erythrocyte damage is not the only factor that affects $C K$ and CK-MB levels in serum samples. The physical structure of IV cannulae and/or deeper penetration in the vein may cause damage to vessel integrity. Kinases released from endothelial cells can interfere with CK and CK-MB. In our comparison of sampling using a $20 \mathrm{G}$ cannula and a $20 \mathrm{G}$ needle unit, all of the tests showed higher levels of CK and CK-MB with the cannula method. In addition, higher $\mathrm{Hb}$ concentrations were detected in blood collected via IV cannula than in blood collected with a needle unit. These results are consistent with findings in the international literature, which have reported that blood collection by IV catheter leads to more hemolysis $[3,12,20]$. Examination of the results indicates that the false-positive effect of hemolysis is much greater on CK-MB activity than CK activity. This is not unexpected for CK-MB activity because the level of this enzyme in the serum is lower than the level of the CK enzyme. We concluded that mild to moderate hemolysis interferes with CK-MB results more than CK results. This result is partially parallel to literature reports indicating that mild hemolysis will not affect the measurement of CK activity [21]. However, mild hemolysis significantly interfered with CK-MB activity measurement according to the results of this study. The primary weakness of this study is that a marker (for example, vasoactive mediators of endothelium origin) was not examined to show vascular endothelial damage. Studies measuring vessel endothelial damage can further explain the mechanisms of non-hemolysis interference in enzyme measurements such as CK-MB.

\section{Conclusion}

In conclusion, hemolysis in a blood sample may falsely exaggerate CK-MB levels and thus mislead a physician who is trying to diagnose a patient with chest pain. To determine whether a patient actually has elevated serum CK-MB activity, care should be taken to avoid hemolysis during blood sample collection, transportation, centrifugation, and examination in the laboratory. Furthermore, measures to exclude hemolysis can be implemented prior to analysis. Our study results showed that blood sampling by IV cannula caused much more mechanical damage to erythrocytes and vessel endothelium than sampling with a needle unit. There was greater interference with CK-MB activity when the cannula method was used.

Conflict of interest: There is no conflict of interest.

Ethics Committee Approval: This research was approved by the Baskent University Faculty of Medicine Clinical Research Ethics Committee (No: KA03/26).

Financial Disclosure: Financial support for this study was provided by Baskent University.

Peer-review: Externally peer-reviewed.

\section{References}

1. Gach O, El HZ, Lancellotti P. Acute coronary syndrome. [Article in French] Rev Med Liege 2018;73:243-50.

2. Akhmedova DI, Akhmedova NR, Aripov AN, Matkarimova AA. Biochemical Markers of Myocardium Damage in Children With Cardiomyopathy. [Article in Russian] Klin Lab Diagn 2019;64(6):337-41. [CrossRef]

3. Lowe G, Stike R, Pollack M, Bosley J, O'Brien P, Hake A, et al. Nursing blood specimen collection techniques and hemolysis rates in an emergency department: analysis of venipuncture versus intravenous catheter collection techniques. J Emerg Nurs 2008;34(1):26-32. [CrossRef]

4. Chang CC, Liou CB, Su MJ, Lee YC, Liang CT, Ho JL, et al. Creatine Kinase (CK)-MB-to-Total-CK Ratio: a Laboratory Indicator for Primary Cancer Screening. Asian Pac J Cancer Prev 2015;16(15):6599-603. [CrossRef]

5. Zhang JQ, Yang QY, Xue FS, Zhang W, Yang GZ, Liao X, et al. Preoperative oral thyroid hormones to prevent euthyroid sick syndrome and attenuate myocardial ischemia-reperfusion injury after cardiac surgery with cardiopulmonary bypass in 
children: A randomized, double-blind, placebo-controlled trial. Medicine (Baltimore) 2018;97(36):e12100. [CrossRef]

6. Kirschner MB, Kao SC, Edelman JJ, Armstrong NJ, Vallely MP, van Zandwijk N, et al. Haemolysis during sample preparation alters microRNA content of plasma. PLoS One 2011;6(9):e24145.

7. Kwon HJ, Seo EJ, Min KO. The influence of hemolysis, turbidity and icterus on the measurements of CK-MB, troponin I and myoglobin. Clin Chem Lab Med 2003;41(3):360-4. [CrossRef]

8. Pateghini M, Renze B. Serum Enzymes. In: Burtis CA, Burns DE, editors. Tietz Fundamentals of Clinical Chemistry and Molecular Diagnostics. 7th ed. Missouri: Elsevier Saunders; 2015. p. 320.

9. Pateghini M, Renze B. Serum Enzymes. In: Burtis CA, Burns DE, eds. Tietz Fundamentals of Clinical Chemistry and Molecular Diagnostics. 7th ed. Missouri: Elsevier Saunders; 2015. p 3212.

10. Thomas L. Haemolysis as Influence \& Interference Factor. EJIFCC 2002;13(4):95-8.

11. Lippi G, Blanckaert N, Bonini P, Green S, Kitchen S, Palicka V, et al. Haemolysis: an overview of the leading cause of unsuitable specimens in clinical laboratories. Clin Chem Lab Med 2008;46(6):764-72. [CrossRef]

12. Haverstick DM, Grosbach AR. Specimen Collection and Processing. In: Burtis CA, Ashwood ER, Bruns DE, editors. Tietz Textbook of Clinical Chemistry and Molecular Diagnostics. 5th ed. Missouri: Elsevier Saunders; 2012. p. 146-8.

13. Horder M, Elser RC, Gerhardt W, Mathieu M, Sampson EJ. International Federation of Clinical Chemistry. Scientific Division, Committee on Enzymes. IFCC methods for the measurement of catalytic concentration of enzymes. Part 7. IFCC method for creatine kinase (ATP: creatine N-phosphotransferase, EC
2.7.3.2). IFCC recommendations. Clin Chim Acta 1990;190(12):S4-S40. [CrossRef]

14. Neumeier D, Prellwitz W, Würzburg U, Brundobler M, Olbermann $M$, Just $\mathrm{H}-\mathrm{J}$, et al. Determination of creatine kinase isoenzyme MB activity in serum using immunological inhibition of creatine kinase M subunit activity. Activity kinetics and diagnostic significance in myocardial infarction. Clin Chim Acta 1976;73(3):445-51. [CrossRef]

15. Higgins T, Eckfeldt JH, Barton JC, Doumas BT. Hemoglobin, Iron, and Bilirubin. In: Burtis CA, Ashwood ER, Bruns DE, editors. Tietz Textbook of Clinical Chemistry and Molecular Diagnostics. 5th ed. Missouri: Elsevier Saunders; 2012. p. 987.

16. Panteghini M, Renze B. Serum Enzyms. In: Burtis CA, Ashwood ER, Bruns DE editors. Tietz Textbook of Clinical Chemistry and Molecular Diagnostics. 5th ed. Missouri: Elsevier Saunders; 2012. p. 569-71.

17. Dasgupta A, Wells A, Biddle DA. Negative interference of bilirubin and hemoglobin in the MEIA troponin I assay but not in the MEIA CK-MB assay. J Clin Lab Anal 2001;15:76-80.

18. Gunduz $H$, Arinc $H$, Yolcu M, Akdemir R, Kanat M, Uyan C. A case of hypothyroidism mimicking acute coronary syndrome. Int J Cardiovasc Imaging 2006;22(2):141-5. [CrossRef]

19. Beck SR. Myocardial injury in critically ill patients. JAMA 1995;274(21):1672-3. [CrossRef]

20. Lippi G, Avanzini P, Cervellin G. Prevention of hemolysis in blood samples collected from intravenous catheters. Clin Biochem 2013;46(7-8):561-4. [CrossRef]

21. Panteghini M, Renze B. Serum Enzyms. In: Burtis CA, Ashwood ER, Bruns DE, editors. Tietz Textbook of Clinical Chemistry and Molecular Diagnostics. 5th ed. Missouri: Elsevier Saunders; 2012. p. 571. 